\title{
International Conference Actual Problems of Organic Chemistry and Biotechnology (OrgChemBioTech2020) April 6-9, 2020, Ekaterinburg
}

The Conference will be held on April 6-9, 2020, at the Ural Federal University (UrFU) named after the first President of Russia B. N. Yeltsin (Ekaterinburg) within the framework of celebration of the 100th year anniversary of the Institute of Chemical Engineering and 70th year birthday of V. A. Bakulev, Professor of the Department of Technology for Organic Synthesis of the Institute of Chemical Engineering of the UrFU.

\section{Organizers}

Institute of Chemical Engineering

Innovative Center for Chemical and Pharmaceutical Technologies

Institute of Natural Sciences and Mathematics, Ural Federal University named after the first President of Russia B. N. Yeltsin

I. Ya. Postovsky Institute of Organic Synthesis, Ural Branch of the RAS

Chairman

Vice-Chairmen

Scientific Secretary

\section{Organizing Committee}

Professor V. A. Bakulev

T. V. Glukhareva, M. V. Varaksin

D. P. Tambasova

T. V. Berezkina
V. S. Berseneva
M. A. Bezmaternykh
O. S. El'tsov
I. V. Geide
M. N. Ivantsova
T. A. Kalinina
I. S. Kiseleva

T. V. Berezkina

O. S. Koptyaeva

M. F. Kosterina

E. G. Kovaleva

A. N. Kozitsina

K. I. Lugovik

O. G. Makeev

M. A. Mironov

T. D. Moseev
Yu. I. Nein
M. S. Novikov
K. L. Obydennov
A. V. Pestov
T. A. Pospelova
V. L. Rusinov
G. L. Rusinov

\author{
E. V. Sadchikova \\ V. Ya. Sosnovskikh \\ O. S. Taniya \\ Yu. M. Shafran \\ I. S. Selezneva \\ M. I. Tokareva \\ G. V. Zyryanov
}

\section{Program Committee}

\author{
Academician (RAS) O. N. Chupakhin \\ Academician (RAS) V. N. Charushin \\ Corr. Member (RAS) V. I. Saloutin \\ Professor V. A. Bakulev \\ Professor N. P. Belskaya
}

\author{
Professor W. Dehan (Belgium) \\ Professor J. J. Fan (China) \\ Professor S. O. Kappe (Austria) \\ Professor V. G. Nenaidenko
}

A. N. Maslivets

Topics for Organic Chemistry Section: achievements of organic synthesis; targeted synthesis of biologically active molecules; new in pericyclic transformations and rearrangements; catalysis and catalytic processes; supramolecular systems and their use in biology and medicine; organic materials for optoelectronics and sensorics; mathematical modeling in the design of organic molecules; molecular docking.

Topics for Biotechnology Section: biotechnology of food products, biologically active substances and medications; preclinical trials of biotechnology products; natural and synthetic biologically active substances as plant growth and stability regulators; plant biotechnology, immuno-and nanobiotechnology; industrial biotechnology; agricultural biotechnology; genetic engineering and biocatalysis in biotechnology.

The program of the Conference includes plenary reports of invited lecturers (40 $\mathrm{min})$; key reports of participants (20 min); oral reports of participants (15 min); reports of young scientists (10 min); poster session; round table "New Trends in Biomedicine" with top Russian and foreign researchers as participants.

\section{Contacts:}

Conference coordinators (registration, recommendations for housing, abstract submission, processing of applications for plenary reports, etc.): Yurii Markovich Shafran and Dar'ya Pavlovna Tambasova.

E-mail: OCBT2020@urfu.ru; tel.: +7 (343) 375 4818, +7 (952) 7448359 (Dar'ya Pavlovna Tambasova). 